\title{
17. ORGANIC GEOCHEMISTRY, DEEP SEA DRILLING PROJECT SITES 415 AND 416: INTRODUCTION AND SUMMARY
}

\author{
Keith A. Kvenvolden, U.S. Geological Survey, Menlo Park, California
}

Organic geochemical studies on samples from two sites in the Moroccan Basin, eastern Atlantic Ocean, provided an opportunity to evaluate processes of organic diagenesis in a tectonically stable continentalrise environment. This evaluation was accomplished by a particularly comprehensive shipboard organic geochemistry program followed by detailed shore-based work conducted by the organic geochemists who served on the Glomar Challenger during Leg 50. Other shorebased laboratories also participated in organic geochemical analyses, but this work was limited to only eight samples. This introductory article briefly reviews some of the pertinent shipboard results. Information obtained from shore-based studies (next 10 papers) augments and extends the preliminary findings and leads to the same general interpretations arrived at from the shipboard studies. In the discussion that follows, papers will be identified by the name of the first author. (The two papers by Galimov et al. are identified as Galimov a and Galimov b; those by Boutefeu are cited as Boutefeu a and Boutefeu b.)

Shipboard results were obtaired by a combination of techniques. Organic-carbon contents were measured on a $\mathrm{CHN}$ analyzer, and gaseous hydrocarbons were determined by gas chromatography. Pyrolysis studies on a newly developed instrument provided an evaluation of the type and maturity of organic matter. Results from this combination of techniques showed that much of the organic matter in the sampled sediments was derived from terrestrial sources and is at an immature stage of evolution.

Samples from Hole 415A came from Lower Cretaceous (upper Albian) to Pleistocene sediments. In the Cenozoic samples, organic-carbon content averaged about 0.4 per cent, whereas that in the Cretaceous samples averaged about 1.06 per cent. Methane was present in all samples. Ethane was found in all samples below 450 meters sub-bottom, and measurable concentrations of ethane, propane, butane, isobutane, and pentane were observed in samples of Cretaceous sediments. Pyrolysis measurements indicated that the organic matter at this site is variable and immature, and that it has a poor potential for hydrocarbon generation.

Samples collected at Site 416 proved to be useful in the study of the diagenesis of organic matter in a sequence of Upper Jurassic to Pleistocene sediments. The concentration of organic carbon averaged about 1.2 per cent in the Cenozoic and 0.8 per cent in the Cretaceous sediments. In the Cretaceous section, the amount of organic carbon decreased with depth, and in general the sediments would not be considered good source beds of petroleum. Gas concentrations were low at the top of the section. Methane increased to nearly 22 per cent by volume of gas at about 900 meters and then decreased to values of 0.1 to 0.5 per cent in the lower part of the section. The relative proportions of ethane, propane, the butanes, and pentane show clear trends in variation with depth below about 1250 meters, where, in the $\mathrm{C}_{2}-\mathrm{C}_{5}$ range of hydrocarbons, ethane predominated and hydrocarbons heavier than propane were absent. With increasing depth, the relative amount of ethane decreased and the heavier hydrocarbons generally increased. Pentane became a major component in this gas mixture at 1500 meters. The pyrolysis studies showed that the organic matter above 1200 meters is immature. Down to a total depth of 1624 meters, the sediments were interpreted to be at the beginning of the mature stage of evolution. The presence of significant concentrations of pentane at depth confirms this state of maturation.

In summary, the conclusions reached on the basis of shipboard work are the following:

1. Much of the organic material in these sediments is terrestrial.

2. Organic matter in sediments ranging from middle Cretaceous to Pleistocene is immature.

3. In Hole 416A in the Lower Cretaceous sequence, the organic matter is at the beginning of the mature stage of evolution.

4. None of the sediments can be considered source beds of petroleum.

The shore-based studies generally support the shipboard results and interpretations. For example, conclusion 1 , that the organic matter is dominantly from terrestrial sources, is supported by:

a) Generally light carbon-isotope compositions (Galimov a, Schorno).

b) Presence of plant fragments: amber, pollen, and spores (Galimov a), and of macerals of higher plants (Cornford).

c) Dominance of $n$-alkanes from higher plant waxes (Claypool, Deroo); values near 1 of the ratio $n-C_{21}+$ $n-\mathrm{C}_{22} /\left(n-\mathrm{C}_{28}+n-\mathrm{C}_{25}\right)$ (Schorno).

d) Relation of organic matter to kerogen type III (Deroo, Boutefeu a).

Although terrestrial organic material dominates, some marine organic matter is also present (Galimova, 
Schorno, Claypool, Deroo, Boutefeu a). A part of the organic matter may be reworked or recycled and altered (Boutefeu a and b, Cornford).

Several investigators make interpretations relative to conclusions 2,3 , and 4 regarding state of maturity of the organic matter and possible presence of petroleum source sediments. Summary statements of their observations or interpretations follow:

a) Evidence for diagenesis and catagenesis is shown by increase of hydrocarbons in bitumens with depth and transition from chlorins to metal porphyrins (Galimov a); nickel porphyrins were observed in both Galimov a and Palmer.

b) Low CPI values (ratio of odd to even-number $n$-alkanes) and high hydrocarbon contents of bitumen in deepest samples in Hole 416A show properties characteristic of oil source sediment (Galimov a).

c) The decrease of CPI (OEP) values with depth indicates increasing maturity (Claypool, Schorno).

d) At 1300 meters in Hole 416A the carbon-isotope composition of methane is the same as the isotopic composition of methane of oil deposits, and this depth corresponds to the uppermost boundary of the zone where petroleum-formation process starts (Galimov b); gases in some sediments are believed to have migrated (Whelan).

e) A progressive thermal alteration occurs with increasing depth, but organic matter is still immature with respect to the degree of alteration required to attain advanced stages of petroleum-hydrocarbon generation (Claypool).

f) Organic matter at the bottom of Hole $416 \mathrm{~A}$ is entering final stages of maturity but is not mature enough to be a source of petroleum (Schorno).

g) Because the conversion of DPEP to etio-series porphyrins is about half complete at 1360 meters in Hole 416A, an advanced stage of diagenesis is indicated (Palmer).

h) Pyrolysis assay shows that organic matter at depth is at an immature stage of evolution just before the principal zone of oil formation, (Deroo, Boutefeu a and $b$ ).

i) Tertiary samples are richest in amorphous kerogen but are immature in terms of petroleum generation (Cornford).

Certainly all of the evidence points to increasing maturity of organic matter with depth. At Hole 416A the organic matter has evolved to the extent that it is on the threshold of being mature. These observations and interpretations are important because they show that in a stable continental-rise environment diagenesis of organic matter can proceed to maturity. Therefore, this kind of environment appears to have the potential to generate petroleum hydrocarbons, and stable continental-rise sediments may constitute an important location for petroleum resources. 